\title{
Gill and Skin Oxygen Uptake, Biochemical, Hematological, and Histological Responses of Eel (Anguilla bicolor bicolor) Exposed to Air
}

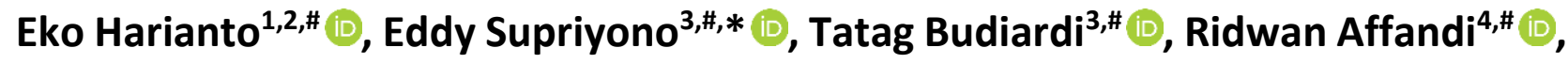 \\ Yani Hadiroseyani ${ }^{3, \# \mathbb{B}}$
}

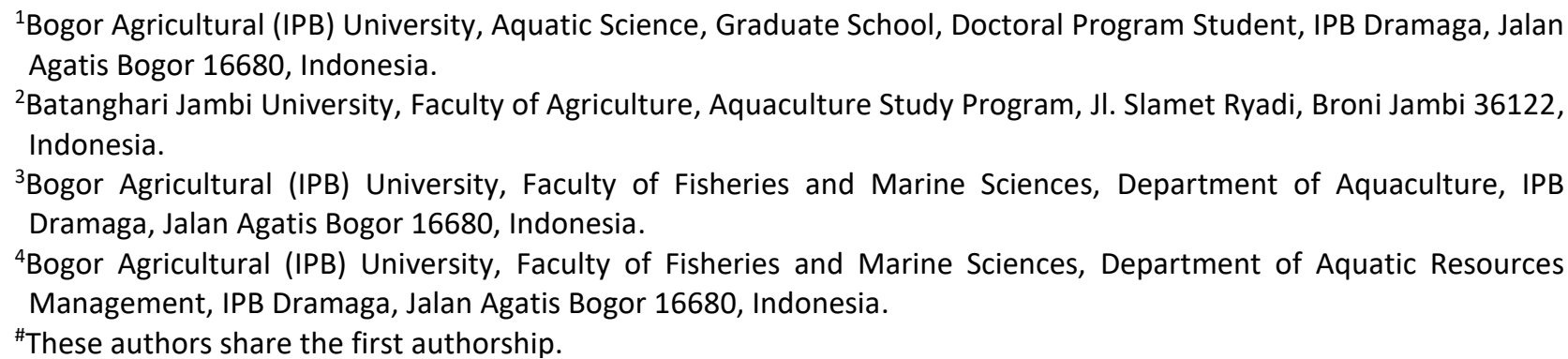

\section{How to cite}

Harianto, E., Supriyono, E., Budiardi, T., Affandi, R., Hadiroseyani, Y. (2022). Gill and Skin Oxygen Uptake, Biochemical, Hematological, and Histological Responses of Eel (Anguilla bicolor bicolor) Exposed to Air. Turkish Journal of Fisheries and Aquatic Sciences, 22(3), TRJFAS19989. http://doi.org/10.4194/TRJFA19989

\section{Article History}

Received 03 June 2021

Accepted 14 October 2021

First Online 14 October 2021

\section{Corresponding Author}

Tel.: +6281287664512

E-mail: eddysupriyonoiipb@gmail.com

\section{Keywords}

Air breathing

Eel

Fisiology response

Oxygen uptake

\begin{abstract}
Research on the Anguilla bicolor bicolor McClelland, 1844 eels has been widely proposed, but study related to air oxygen uptake through gills and skin for $A$. bicolor bicolor has not been found. This information is very important in the development of future cultivation technology. This study aims to analyze the oxygen uptake of $A$. bicolor bicolor through gills and skin, blood biochemistry, blood image and histology to air exposure. Eels were exposed to air for one hour (A), two hours (B) and three hours (C), and eels in the water were used as control. A total of 66 fish $(77.68 \pm 1.54 \mathrm{~g})$ of eels were imported from Bogor City, Indonesia. Oxygen uptake from the air through the gills and skin reduced with longer exposure time. After 3 hours of exposure time, the percentage of oxygen uptake through the gills decreased from $64.52 \%$ to $54.29 \%$ and the percentage of oxygen uptake through the skin increased from $35.48 \%$ to $45.71 \%$. Eels use different proportions of their gills and skin together when exposed to air. Air exposure affected the blood biochemistry values, blood image and showed the highest values on air exposure for 3 hours.
\end{abstract}

\section{Introduction}

Anguilla bicolor bicolor McClelland, 1844 is a type of shortfin eel which is found in most waters in Indonesia (Affandi et al., 1995; Chino \& Arai, 2010; Arai, 2013, Arai \& Kadir, 2017; Arai \& Chino, 2018). According to Robinet and Feunteun (2002); Haryono and Wahyudewantoro (2016) spawning locations for $A$. bicolor bicolor eel is one of which is in the Indonesian Ocean, southwestern part of Sumatra. A. bicolor bicolor is a catadromic species, which spawns in the sea and grows in fresh water and returns to the sea to spawn after maturing (McKinnon, 2006; Arai \& Chino, 2019).
During the migration, $A$. bicolor bicolor eels often face to face extreme water conditions both in quality and quantity (Tesch, 2003). When migrating to the upstream (fresh water), eels sometimes encounter limited water, semi-dry rivers, and receding seawater. These conditions sometimes cause eels to be directly exposed to air (Hyde et al., 1987).

Direct exposure to air in a relative long time allows eels to face hypoxic and hypercapnia conditions. Hyde and Perry (1987) explained that eels that are out of water for 36 hours are able to withstand hypoxemia and acidosis with anaerobic respiration mechanisms due to from a large loss of oxygen in the gills. Harianto et al., 
(2020) reported that eels can survive outside of water for 3 days or 72 hours because they have an additional respiratory organ, namely the skin. The skin is an additional respiration tool for eels and is used when dissolved oxygen is low. Berg and Steen (1965) stated that when eels are in the water, $90 \%$ of oxygen is absorbed in the gills while in the air about two-thirds of oxygen consumption is absorbed by the skin. The structure of the skin of eels is strong and resistant to external effects, especially in the epidermis with a thick chorium structure which allows all oxygen needs to be fulfilled quickly (Tesch, 2003).

Another consequence that will occur if the eels are outside the water medium is the disruption of physiological processes, including the respiratory system and blood biochemical indicators. In the gills, the filaments will stick to each other and result in nonfunctioning gas exchange by other organs (gill lamellae, respiratory tract). (Cook et al., 2015; Ferguson and Tufts 1992). Aerobic respiratory system that is not functioning or stopped will force fish to do anaerobic respiration. This condition causes the accumulation of carbon dioxide and lactic acid, thereby reducing the $\mathrm{pH}$ concentration in the blood (Ferguson and Tufts 1992; Suski et al. 2004). Other physiological impacts will be seen as long as the fish are exposed to air, in other words, the fish are in an asphyxia condition where the hormonal response will occur with the active hypothalamic-pituitary-interrenal process, thereby triggering an increase in the distribution of lactic acid, cortisol and glucose (Cook et al. 2015; Arends. et al. 1999) These physiological and respiratory responses indicate that fish are under stress, which will directly affect growth and production performance.

Physiological responses and respiratory adaptation when eels are out of water are interesting to study as the basis for developing cultivation systems and transportation processes. Several related studies have been reported for European eel A. anguilla, (Krogh, 1904; Berg \& Steen, 1965, 1966), American eel $A$. rostrata (Hyde et al., 1987; Hyde \& Perry, 1987; Tomie et al. al., 2013), and the Asian short-finned eel $A$. australis schmidtii (Forster, 1981). No data and available information availabe for eel $A$. bicolor bicolor regarding physiological responses and respiratory adaptation when outside water. The objective of this study is to analyze the oxygen uptake responses of $A$. bicolor bicolor eels through gills and skin, blood biochemistry, blood images, and histology to air exposure.

\section{Materials and Methods}

\section{Experimental Fish Preparation}

A total of 66 elver eels as experimental fish were acquired from eel farmers in Bogor City, Indonesia with an average weight of $77.68 \pm 1.54 \mathrm{~g}$. Three eels $(78.83 \pm 2.31 \mathrm{~g})$ were used to measure the air oxygen uptake through the gills, the other three $(80.60 \pm 2.55 \mathrm{~g})$ were used to measure the air oxygen uptake through the skin. The remaining 60 eels were utilized for physiological response analysis, including blood biochemistry, blood images and gill and skin histology.

\section{Respirometer Preparation}

This study used a volumetric respirometer to measure the oxygen uptake of eels from the air. The usage of a respirometer refers to Elliot (1968); Scholander et al. (1955) with minor modifications (Figure 1). Modifications were made by adding water to the aquarium as a medium that aims to maintain temperature stability. The respirometer was equipped with a U-shaped tube placed on the wall of a scale board, eosin solution, $\mathrm{KOH} 90 \%$, vaseline and a mercury thermometer.

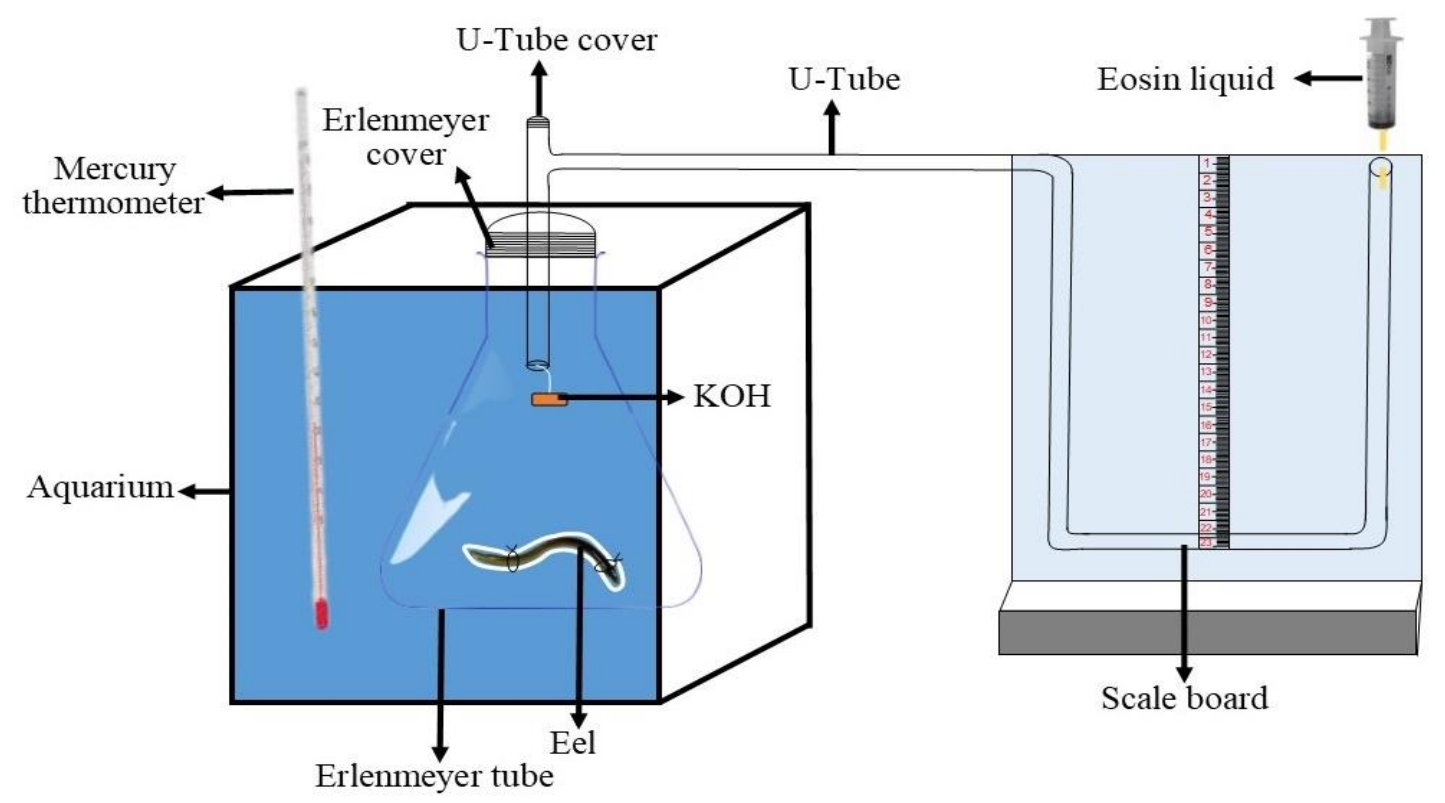

Figure 1. Volumetric respirometer design 


\section{Research Design}

The research design was carried out in two separate parts. The first was the measurement of air oxygen uptake through the gills and skin and the second was histological analysis of the gills and skin, blood biochemical analysis and blood pictures. The study used a completely randomized design (CRD) with three treatments, namely eels exposed to air for one hour (A), two hours (B) and three hours (C), eels in the air were used as a control. Measurement of oxygen uptake was carried out alternately, because there was only one respirometer. Measurement of air oxygen uptake through gills and skin using test fish as many as 6 individuals, 3 individuals for gill absorption and 3 individuals for skin absorption. Data was taken every 15 minutes for 3 hours on each test fish and served according to the treatment. So from a fish was got oxygen uptake data for 1, 2 and 3 hours.

Histological and skin analysis measurements, blood biochemistry and blood pictures were carried out according to the treatment in plastic containers measuring $68 \mathrm{~cm} \times 47 \mathrm{~cm} \times 39 \mathrm{~cm}$, these containers were used for fish analysis when exposed to the air. The number of containers used was 12 units. Nine units of containers for treatment A, B and C, each containing 3 replications, as well as 3 units of other containers used as control containers where eels were kept in water using the same plastic container. In treatments A, B and $C$, they were left empty (without air) and placed indoors, each container filled with five eels. The test fish were left in the appropriate container for treatment. The test fish were taken at the end of the treatment with the distribution of one individual eel used for histological analysis of gills and skin and four others used for biochemical analysis of blood and images.

\section{Blood Sampling}

Blood samples were taken by anesthetizing the

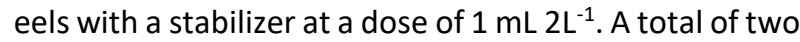
blood samples were collected at the upper part between the anus and the tip of the anal fin. The first blood sample was taken as much as $0.5 \mathrm{~mL}$ with a syringe containing an anticoagulant ( $\mathrm{Na}$-citrate) and put into an Eppendorf tube according to the treatment. The second blood sample was taken as much as $1.5 \mathrm{~mL}$ without anticoagulant and put into the EDTA tube according to the treatment. Both procedures occurred in 10-15 minutes. The first blood sample was set for blood image analysis and the second blood sample was set for the biochemistry analysis of blood.

\section{Air Oxygen Uptake Through Gills and Skin}

The uptake of oxygen from the air through the skin and gills by the eels was measured and observed using a volumetric respirometer. The uptake of oxygen through the gills was carried out by means of the base of the pectoral fin until the end of the test fish tail is closed with latex rubber and tied with thread, then closed again with crepe paper tape, then tied back with thread. The test fish was rewrapped with waring and given a weight then put into the Erlenmeyer tube. The absorption of oxygen from the air through the skin is carried out by means of the tip of the head until the gills are cove'red with latex rubber and tied with threads, then covered again with tape from crepe paper, then tied back with threads. After the head was wrapped with rubber and tape, the test fish was rewrapped with waring and given a weight and then put into the Erlenmeyer tube.

The procedure for calculating and converting air oxygen uptake through the gills and skin was carried out by calculating the difference in the height of eosin movement (Tt-TO in $\mathrm{mL}$ ) then converted into weight units of test eels and time of observation. The calculation is in accordance with the formula:

$$
\operatorname{Vol~} O_{2}=p h i \times r^{2} \times(h t-h 0) / \mathrm{w} / t
$$

Vol $\mathrm{O}_{2}=$ Oxygen volume ( $\mathrm{mg} \mathrm{O} \mathrm{O}_{2} \mathrm{~g}^{-1}$ hour $)$

$r=$ Radius of tube $U(\mathrm{~cm})$

$\mathrm{h} 0=$ Initial height of eosin $(\mathrm{cm})$

$\mathrm{ht}=$ Eosin height at time $\mathrm{t}(\mathrm{cm})$

$\mathrm{w}=$ Fish weight $(\mathrm{g})$

$\mathrm{t}=$ Observation time (hour)

\section{Percentage of Air Oxygen Uptake}

The percentage of air oxygen uptake through the gills and skin is calculated using the following formula:

$$
\text { Gills oxygen uptake } \%=\frac{\begin{array}{c}
\text { Oxygen absorption } \\
\text { from the gills }
\end{array}}{\begin{array}{c}
\text { Total oxygen uptake } \\
\text { in the gills }
\end{array}} \times 100
$$

$$
\text { Skin oxygen uptake } \%=\frac{\begin{array}{c}
\text { Oxygen absorption } \\
\text { from the skin }
\end{array}}{\begin{array}{c}
\text { Total oxygen uptake } \\
\text { in the skin }
\end{array}} \times 100
$$

\section{Blood Biochemistry Analysis}

The analysis was carried out on blood glucose (BG), total protein (TP), total cholesterol (TC), total triglycerides (TG), serum glutamic pyruvic transaminase (SGPT), serum glutamic oxaloacetic transaminase (SGOT), and alkaline phosphatase (ALP). Blood samples from the EDTA tube were taken with a $1 \mathrm{~mL}$ syringe, then transferred into the analysis tube and put into the ARKRAY blood chemical analyzer machine (SPOTCHEMEZ sp 4430). Paper test indicators were prepared and arranged on a panel inside the tool. The blood chemical analyzer machine was set and coded according to the treatment, the analysis on the machine lasted 10 minutes, the results automatically came out in the form of a print out. 


\section{Blood Image Analysis}

Blood image analysis included red blood cells $(\mathrm{RBC})$, white blood cells (WBC), hemoglobin ( $\mathrm{Hb})$ and hematocrit (He). The amount of RBC and WBC was calculated according to Blaxhall \& Daisley, (1973), Hb levels were carried out by the Sahli method with a sahlinometer (Wedemeyer \& Yasutake, 1977), and He levels were calculated according to (Anderson \& Siwicki, 1993).

\section{Histological Analysis}

Gills and skin samples were collected by anesthetic overdose of the fish using a stabilizer then were cut at the base of the head to take the gills and the back of the fish was cut vertically to remove the skin using scissors and tweezers. The histology preparations of skin and gill organs were made according to the method of Angka et al. (1990) and carried out by fixing the organ samples with Bouin's solution, dehydrated in an alcohol solution ranging from $70 \%$ to absolute, then infiltrated and blocked in liquid paraffin (Sigma). Histology preparations were stained with hematoxylin and eosin (HE) and then the preparations were observed under a microscope with a magnification of $40 x$. The results of the analysis are in the form of images equipped with a $50 \mu \mathrm{m}$ bar scale.

\section{Data Analysis}

The data obtained were tabulated with Microsoft Excel 2013 program. Data on air oxygen uptake through gills and skin, blood biochemical analysis, and blood images were analyzed by ANOVA at 95\% confidence interval using SPSS 22.0 program. If there was a significant difference, further tests were carried out using the Duncan test method to see the differences between treatments. Histological analysis is presented in the form of images and being analyzed descriptively.

\section{Results}

The uptake of oxygen from the air through the skin and gills by eels was measured and observed with a volumetric respirometer, the value of carbon dioxide was not measured and assumed to be absorbed by the $\mathrm{KOH}$ compound on the respirometer (Scholander \& Edwards, 1942). The water temperature outside the respirometer was $26{ }^{\circ} \mathrm{C}-27{ }^{\circ} \mathrm{C}$. The uptake of oxygen from the air through the gills and skin is shown in Table 1. Air exposure given to eels showed a significant difference $(P<0.05)$ for the oxygen uptake from the air through the gills, while it did not have significant effect for the oxygen uptake from the air through the gills and skin and for the oxygen uptake from the air through the skin (Table 3). The oxygen uptake of eels from the air through the gills and skin both reduced with increasing observation time. The air oxygen uptake of eels through the gills for 1,2 and 3 hours, respectively, was $0.10,0.06$ and $0.032 \mathrm{mgO}^{2} / \mathrm{g} /$ hour. The oxygen uptake through the skin for 1, 2 and 3 hours, respectively, was $0.05,0.04$ and $0.029 \mathrm{mgO}^{2} / \mathrm{g} /$ hour. The percentage of oxygen uptake from the air through the gills decreased over time from $64.52 \%-54.29 \%$, while the percentage of oxygen uptake from the air through the skin increased from $35.48 \%$ $45.71 \%$. The highest total oxygen uptake was still found when the eels were in the water with an average absorption of $0.133 \mathrm{mLO}^{2} \mathrm{~g}^{-1}$ hour ${ }^{-1}$.

Blood biochemistry responses had significant effect $(P<0.05)$ on BG, TC, TG, SGPT, SGOT and ALP but had no significant effect $(P>0.05)$ on TP (Table 2$)$. The TC and TG values of treatment $C$ were $265,251 \mathrm{mg} / \mathrm{dL}$ and $558.20 \mathrm{mg} / \mathrm{dL}$, respectively. These values were higher than treatment $A$ and $B$. The values of BG, SGPT, SGOT and ALP in treatment $C$, which were $178.17 \mathrm{mg} / \mathrm{dL}$,

Table 1. The oxygen uptake of $A$. bicolor bicolor through the gills and skin on air exposure for 1 hour (A), 2 hours (B), and 3 hours (C).

\begin{tabular}{|c|c|c|c|c|c|c|c|c|c|}
\hline \multirow[t]{2}{*}{ Treatments } & \multirow[t]{2}{*}{ Repetition } & \multirow{2}{*}{$\begin{array}{c}\text { Fish sample } \\
\text { number (gills) }\end{array}$} & \multirow{2}{*}{$\begin{array}{c}\text { Fish sample } \\
\text { number (skin) }\end{array}$} & \multicolumn{3}{|c|}{$\begin{array}{l}\text { Oxygen uptake form } \\
\text { (mgO2/g/hour) }\end{array}$} & \multirow[t]{2}{*}{$\begin{array}{l}\text { Air total oxygen uptake } \\
\left(\mathrm{mgO}_{2} / \mathrm{g} / \text { hour }\right)\end{array}$} & \multicolumn{2}{|c|}{ Uptake percentage (\%) } \\
\hline & & & & Water & Gill & Skin & & Gill & Skin \\
\hline & 1 & 1 & 4 & & 0,09 & 0,08 & 0,17 & 52,44 & 47,56 \\
\hline \multirow[t]{4}{*}{ A (1 jam) } & 2 & 2 & 5 & $0,133^{*}$ & 0,12 & 0,04 & 0,16 & 77,48 & 22,52 \\
\hline & 3 & 3 & 6 & & 0,08 & 0,05 & 0,13 & 63,63 & 36,37 \\
\hline & & & & Average & $0,10^{b}$ & $0,05^{a}$ & 0,15 & $64,52^{a}$ & $35,48^{a}$ \\
\hline & & & Standard err & of mean & 0,02 & 0,02 & 0,02 & 12,54 & 12,54 \\
\hline \multirow[t]{5}{*}{ B (2 jam) } & 1 & 1 & 4 & & 0,06 & 0,05 & 0,11 & 51,25 & 48,75 \\
\hline & 2 & 2 & 5 & $0,133^{*}$ & 0,08 & 0,03 & 0,10 & 73,95 & 26,05 \\
\hline & 3 & 3 & 6 & & 0,05 & 0,03 & 0,08 & 60,13 & 39,87 \\
\hline & & & & Average & $0,06^{a}$ & $0,04^{a}$ & 0,10 & $61,78^{a}$ & $38,22^{a}$ \\
\hline & & & Standard err & of mean & 0,01 & 0,01 & 0,02 & 11,44 & 11,44 \\
\hline \multirow[t]{5}{*}{ C (3 jam) } & 1 & 1 & 4 & & 0,03 & 0,04 & 0,07 & 39,82 & 60,18 \\
\hline & 2 & 2 & 5 & $0,133^{*}$ & 0,04 & 0,02 & 0,06 & 68,11 & 31,89 \\
\hline & 3 & 3 & 6 & & 0,03 & 0,02 & 0,05 & 54,95 & 45,05 \\
\hline & & & & Average & $0,03^{a}$ & $0,03^{a}$ & 0,06 & $54,29^{a}$ & $45,71^{a}$ \\
\hline & & & Standard err & of mean & 0,01 & 0,01 & 0,01 & 14,16 & 14,16 \\
\hline
\end{tabular}

Data are presented as mean \pm standard error of mean. No statistical analyzes were performed on fish control treatment. The values with same letters in the same line indicate non-significant differences ( $P>0.05)$ in $5 \%$ significance level. One-way analysis of variance (ANOVA) followed by Duncan's multiple-range test was used to test significant differences among groups. *Kim et al. 2014 
Table 2. Blood biochemical parameters of $A$. bicolor bicolor on air exposure for 1 hour (A), 2 hours (B), and 3 hours (C).

\begin{tabular}{lcccc}
\hline \multirow{2}{*}{ Parameters } & \multicolumn{4}{c}{ Air exposure period (hour) } \\
\cline { 2 - 5 } & Control (0) & A (1) & B (2) & 13 ( $)$ \\
\hline BG (mg/dL) & $78,60 \pm 16,52$ & $99,33 \pm 18,06^{\mathrm{a}}$ & $161,00 \pm 10,21^{\mathrm{b}}$ & $178,17 \pm 17,62^{\mathrm{b}}$ \\
TP (g/dL) & $7,50 \pm 2,31$ & $6,87 \pm 1,10^{\mathrm{a}}$ & $7,77 \pm 1,54^{\mathrm{a}}$ & $7,63 \pm 50,54^{\mathrm{a}}$ \\
TC (mg/dL) & $146,66 \pm 10,67$ & $126,20 \pm 5,54^{\mathrm{a}}$ & $128,57 \pm 8,58^{\mathrm{a}}$ & $265,251 \pm 36,41^{\mathrm{b}}$ \\
TG (mg/dL) & $213,1 \pm 10,24$ & $330,45 \pm 7,28^{\mathrm{a}}$ & $398,00 \pm 74,95^{\mathrm{b}}$ & $558,20 \pm 25,74^{\mathrm{c}}$ \\
SGPT (IU/L) & $1,33 \pm 0,08$ & $5,94 \pm 2,68^{\mathrm{a}}$ & $29,00 \pm 7,07^{\mathrm{ab}}$ & $33,87 \pm 0,32^{\mathrm{b}}$ \\
SGOT (IU/L) & $24,26 \pm 2,62$ & $13,22 \pm 4,52^{\mathrm{a}}$ & $55,95 \pm 16,76^{\mathrm{b}}$ & $60,27 \pm 7,35^{\mathrm{b}}$ \\
ALP (IU/L) & $341,2 \pm 0,90$ & $274,25 \pm 70,36^{\mathrm{a}}$ & $437,00 \pm 19,80^{\mathrm{b}}$ & $457,00 \pm 5,66^{\mathrm{b}}$ \\
\hline
\end{tabular}

Data are presented as mean \pm standard error of mean. No statistical analyzes were performed on fish control treatment. The values with same letters in the same line indicate non-significant differences $(P>0.05)$ in $5 \%$ significance level. One-way analysis of variance (ANOVA) followed by Duncan's multiple-range test was used to test significant differences among groups; BG: blood glucose, TP: total protein, TC: total cholesterol, TG: total triglycerides, SGPT: serum glutamic pyruvic transaminase, SGOT: serum glutamic oxaloacetic transaminase, ALP: alkaline phosphatase

Table 3. The hematological parameters of $A$. bicolor bicolor on air exposure in for 1 hour (A), 2 hours (B), and 3 hours (C).

\begin{tabular}{lcccc}
\hline \multirow{2}{*}{ Parameters } & \multicolumn{4}{c}{ Air exposure period (hour) } \\
\cline { 2 - 5 } & Control $(0)$ & $\mathrm{A}(1)$ & $\mathrm{B}(2)$ & $\mathrm{C}(3)$ \\
\hline RBC $\left(\times 10^{6}\right.$ cells/mm) & $2,67 \pm 0,12$ & $1,86 \pm 0,27^{\mathrm{a}}$ & $1,79 \pm 0,06^{\mathrm{a}}$ & $2,00 \pm 0,3^{\mathrm{a}}$ \\
WBC $\left(\times 10^{4} \times\right.$ cells/mm) & $9,76 \pm 0,82$ & $8,08 \pm 1,66^{\mathrm{a}}$ & $7,06 \pm 0,07^{\mathrm{a}}$ & $8,11 \pm 1,34^{\mathrm{a}}$ \\
Hb (g \%) & $13,8 \pm 1,00$ & $11,27 \pm 1,29^{\mathrm{a}}$ & $10,93 \pm 0,99^{\mathrm{a}}$ & $10,33 \pm 2,48^{\mathrm{a}}$ \\
He $(\%)$ & $37,5 \pm 2,28$ & $29,73 \pm 1,29^{\mathrm{a}}$ & $30,33 \pm 0,31^{\mathrm{a}}$ & $31,27 \pm 1,89^{\mathrm{a}}$ \\
\hline
\end{tabular}

Data are presented as mean \pm standard error of mean. No statistical analyzes were performed on fish control treatment. The values with same letters in the same line indicate non-significant differences $(P>0.05)$ in $5 \%$ significance level. One-way analysis of variance (ANOVA) followed by Duncan's multiple-range test was used to test significant differences among groups; $R B C=$ red blood cells, $W B C=$ white blood cells, $\mathrm{Hb}=$ hemoglobin, $\mathrm{HE}=$ haematocrit.

33.87 IU / L, 60.27 IU / L and 457.00 IU / L respectively, were higher than with treatment $A$, but equal to higher than treatment B.

The air exposure treatments given to eels did not show any significant effects $(P>0.05)$ for all blood image parameters (Table 3 ). RBC values ranged from 1.86 $2.00 \times 106$ cells $/ \mathrm{mm}^{3}$, WBC values ranged from 7.06-8.11 x 104 cells $/ \mathrm{mm}^{3}, \mathrm{Hb}$ values ranged from $10.33-11.27 \mathrm{~g} \%$, He values ranged from $29.73-31.27 \%$.

The histology of the gill organs and skin of eels exposed to air for one, two and three hours is shown in Figure 2. The histology structure of the gill organs and skin of eels showed necrosis in treatments $A$ ( 1 hour) and $C$ ( 3 hours) and hyperplasia in treatment $B$ ( 2 hours). In the skin, epidermal erosion occurs in all treatments.

\section{Discussion}

Eel (A. bicolor bicolor) is a fish that can live in extreme water conditions (Tesch, 2003). One of the extreme conditions often experienced by eels is a change in water to dry conditions when migrating. Eel species ( $A$. bicolor bicolor) can live for three days in dry conditions and six days in humid conditions (Harianto et al., 2020). The ability to live in these conditions is supported by the mechanism of respiration, namely by using the skin as an additional respiratory organ when the eels are in less oxygen condition in water. Tesch (2003) stated that eels use their skin to breathe when they are outside and use their gills when they are in the water. Research on air oxygen uptake by fish has previously been carried out with volumetric respirometers (Scholander \& Edwards, 1942;
Scholander, 1949). The uptake of air oxygen through the skin of $A$. anguilla eel species is $60 \%$ at $22^{\circ} \mathrm{C}$, $A$. vulgaris species is $67 \%$ at $7{ }^{\circ} \mathrm{C}$ and $45 \%$ at $15^{\circ} \mathrm{C}$ (Krogh, 1904; Berg \& Steen, 1965).

In this study, the eels used as experimental fish was A. bicolor bicolor. The uptake of air oxygen through the skin and gills was carried out at a temperature of $26^{\circ} \mathrm{C}$. Based on the data in Table 1, it can be seen that there is a decrease in the percentage of air oxygen uptake through the gills and an increase in the percentage of oxygen uptake through the skin. The percentage of air oxygen uptake through the gills was $64.52 \%$ (Treatment A), $61.78 \%$ (Treatment B), $54.29 \%$ (Treatment C). The percentage of air oxygen uptake through the skin was $35.48 \%$ (Treatment A), 38.22\% (Treatment B), $45.71 \%$ (Treatment C). The percentage of air oxygen uptake through the skin in this study was lower than the results by Krogh (1904) and Berg and Steen (1965) which stated that the air oxygen absorption of eels through the skin was $60 \%$ and $40 \%$ through gills. This is greatly influenced by the air exposure time. The air exposure in this study was still relatively short for this species, eels still kept water reserves in the gill cavities which were used as oxygen reserves when outside the water medium, so that the skin did not function optimally in absorbing oxygen. However, trends have shown that skin respiration begins to dominate with increasing observation time. Eel is a group of fish that is able to absorb oxygen directly from the air through the skin (Graham, 1997) so that this fish is capable to adapt to the low oxygen conditions experienced during upstream migration (fresh water) or when eels dig holes for hiding (Van Waarde et al., 1983, Hyde et al., 1987, Graham, 


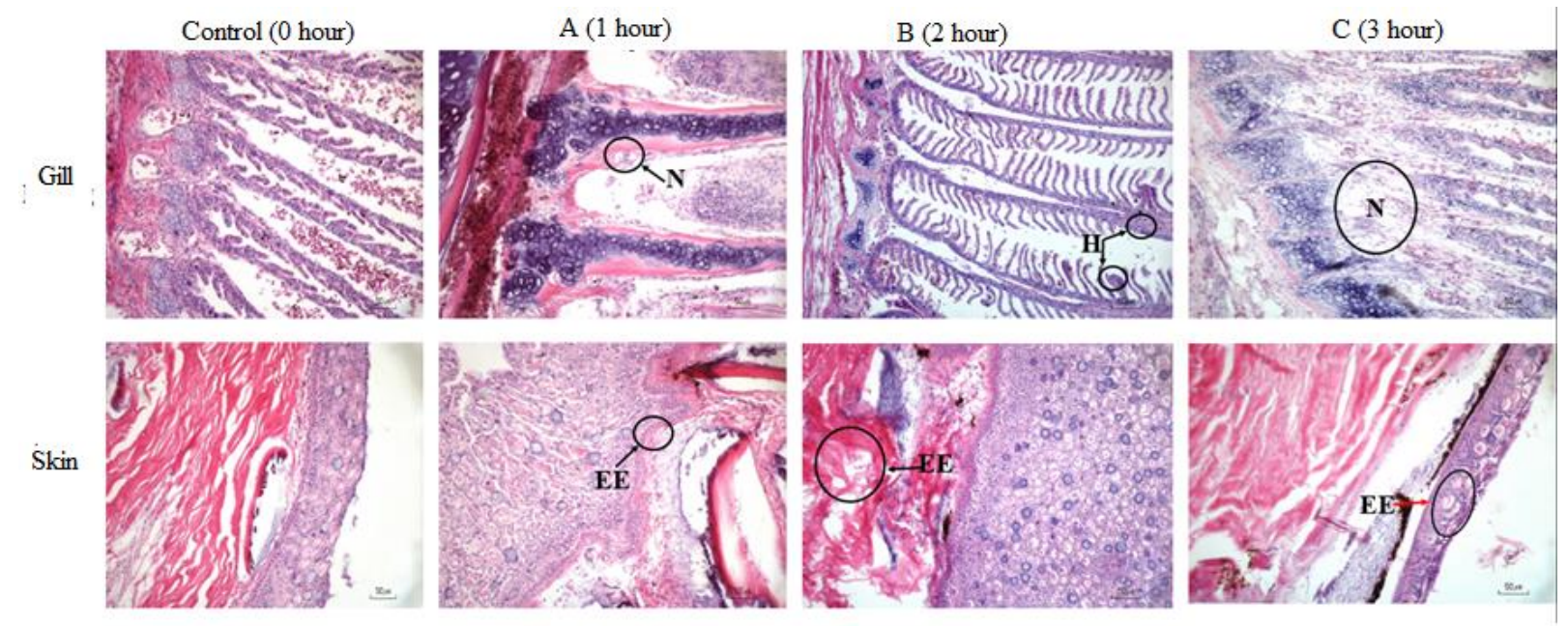

Figure 2. The histology of the gills and skin of A. bicolor bicolor on air exposure in for 1 hour (A), 2 hours (B), and 3 hours (C) air exposures. $\mathrm{N}=$ Necrosis, $\mathrm{H}=$ Hyperplasia, $\mathrm{EE}=$ Epidermal erosion, Hematoxylin-Eosin staining 40x (f) bar $=50 \mu \mathrm{m}$.

1997). Eels have a high ability among other teleost fish which makes them able to live on land in a short time (Lindsey, 1978).

Air exposure has a direct effect on physiological process of the fish. The condition outside the water media resembles a hypoxic condition and will further affect the respiration process, namely the bonding of the gill lamellae and causing the failure of aerobic respiration (Ferguson \& Tufts, 1992). The longer the fish are exposed to air is the main reason for acute stress because the hypothalamic-pituitary-interrenal axis triggers a physiological stress response which results in increasing lactic acid, glucose, cortisol and other blood chemicals (Trischitta, 2013). The study of physiological stress responses in eels has been reported with various stressors, including environmental stressors, temperature, hypoxia, hypercapnia, $\mathrm{pH}$ and ammonia (McKenzie et al., 2003), stocking density (Huertas \& Cerda, 2006; Harianto; et al., 2014; Tan et al., 2018), transportation (Boerrigter et al., 2013; Taqwa et al., 2018). The stress response of $A$. bicolor bicolor eels due to air exposure has not been widely reported, so the approach taken is a stress response due to other treatments.

Air exposure in this study revealed a stress response in eel where three hours of air exposure (Treatment C) showed the highest stress response compared to other treatments at the values of BG, TG, SGPT, SGOT and ALP. Similar results were also reported where eels exposed to the air for 36 hours experienced a change in acid-base status and a long recovery period after being returned to the water (Hyde \& Perry, 1987). The value of BG in this study is $178.17 \mathrm{mg} / \mathrm{dL}$. This value is still in normal conditions for eels, after three hours of exposure to the air, the eels were still alive and able to return to normal conditions at a fast time. Normal BG values in eel were also reported in previous studies, which ranged from 31-186 mg / dL (Harianto et al., 2014; Diansyah et al., 2014; Fekri et al., 2018; Taqwa et al., 2018). In addition, the increased value of $B G$ is due to the fact that eels require high energy to adapt to the treatment given so that energy needs are obtained from the glycogenolysis process, liver BG is released into the blood to provide sufficient BG as a source of metabolic energy, increasing levels of $B G$ are the result of the breakdown of liver glycogen, this process aims to keep eels alive (Chen et al., 2017; Dutra et al., 2008).

TP values were the same for all treatments ranging from 6.87-7.63 g /dL and were still in normal conditions. TP values were also found to be between $4-42.42 \mathrm{~g} / \mathrm{dL}$ in other studies (Sancho et al., 2016; Tan et al., 2018; Refaey \& Li, 2018). TP is a physiological response that is used as an indicator of fish health (Tahmasebi-Kohyani et al., 2012). Air exposure to fish causes a decrease in TP (Jackim \& La Roche, 1973). In contrast to the TP value, the TC and TG values of Treatment C (126-265 g /dL $330-558 \mathrm{~g} / \mathrm{dL}$ ) showed the highest values compared to other treatments. Increased levels of TC and TG is a stress indicator of eels where total lipids are maximally synthesized to be converted to cholesterol and triglycerides so that they can be used as an energy source. In addition, the condition of air exposure affects impaired liver function, where in the production of ATP multiplies from the breakdown of glycogen in both the muscles and the liver. Disruption of air exposure requires eels to remain stable and live towards homeostatic conditions so that they require high energy. Increased TC and TG are part of liver dysfunction and lipid metabolism disorders (Javed et al., 2017). The TC and TG levels in the species Dicentrarchus labrax were reported to be 406 and $272 \mathrm{mg} / \mathrm{dL}$ (Perez-Jimenez et al., 2007; Chatzifotis et al., 2011). Sancho (2016) stated that $A$. anguilla eels exposed to propanyl showed an increase in TC and TG levels by $34 \%-45 \%$ and $100 \%$ compared to controls ( 267.7 and $186.7 \mathrm{~g} / \mathrm{dL}$ ).

The composition of SGPT, SGOT and ALP in Treatment C were 33.87, 60.27 and 457.00 I / UL, respectively. These values are higher than Treatment $A$ but were as the same as Treatment B. The SGPT and SGOT values are groups of enzymes that are directly 
related to the liver, the increase in SGPT is often used as an indicator of liver function damage (Kulkarni \& Pruthviraj, 2016). ALP is an enzyme that functions to convert organic into inorganic phosphate. This enzyme also plays a role in responding to tissue damage, especially the liver, so it is widely used in toxicological studies (Triphati \& Singh, 2003). The increase in the value of SGPT, SGOT and ALP in this study was the effect of air exposure, the longer the eels are exposed to air, the longer eels continue to be in a hypoxic and hypercapnia state. This condition has a direct effect on the performance of the liver in producing energy, a liver that works harder will experience malfunctioning. SGPT and SGOT values will increase if there is liver damage such as hepatocellular necrosis and cause intaracellular release of enzymes into the blood (Yang \& Chen, 2003; Perez-Rostro et al., 2004; Hidayaturrahmah et al., 2015). Sripriya et al. (2015) reported that there was a seasonal fluctuation in the value of SGPT and SGOT in A. bicolor bicolor eels. An increase in ALP greater than $50 \%$ occurred when the eels were exposed to propanyl with a control ALP value $(35.46 \mathrm{nmol} / \mathrm{min} / \mathrm{mL}$ ) (Sancho et al., 2016).

Blood image is one of the physiological responses in seeing the health status of fish caused by stress factors so that it can provide a comparative reference in aquaculture (Fazio et al., 2012; Dikic et al., 2013). Air exposure is closely related to hypoxic conditions which can cause an increase in the value of $\mathrm{HR}, \mathrm{Hb}$ and $\mathrm{He}$ in the blood (Wells \& Baldwin, 2006; Abdel-Tawwab et al., $2014,2015)$. Based on the results of the study, it can be seen that all blood image parameters show the same response for all treatments (Table 3 ). The same results were also found in eels that were kept at high density and showed the same blood image response (Harianto et al., 2014). Blood image parameters have not shown specific results for air exposure, this is due to the relatively short exposure time, so that the eels are still able to maintain their physiological conditions. Eels are strong fish with extreme environmental changes and are able to live for 36 and 72 hours (Hyde \& perry, 1987; Tesch, 2003; Methling, 2015).

Histology is one of the important aspects in observing the health status of fish by detecting at the beginning that fish are experiencing stress due to disease attacks or other factors that are impossible to see with a rough examination (Mumford, 2004) and is often used as biomarkers of fish health (De Domenico et al., 2013; Cappello et al., 2016; Yancheva et al., 2016). Changes in the histological structure of several vital organs of eel occur due to disease attacks and contaminants that take place in the waters (Hangalapura et al., 2007; Caruso et al., 2009; Capaldo et al., 2018; Harianto et al., 2020).

Air exposure treatments given to eels in this study had an effect on changes in the histology structure of the gills and skin. In the gill organs, necrosis of the lamellae was found and hyperplasia on the gill filaments. This occurred due to a disturbance in the gas exchange process, the balance of the liquid entering and leaving was irregular, causing the gills to experience a little dryness of the liquid. Necrosis and hyperplasia also occured in $A$. japonica eels due to exposure to metal mercury and infection with Herpesvirus anguillae (Tang et al., 2019). Hyperplasia also appeared in A. bicolor bicolor eels that were maintained with low water levels (Harianto et al., 2020). Hyperplasia and necrosis are common in mucus-secreting organs (Flores-Lopes \& Thomaz 2011). Hyperplasia results in reducing the ability of heart to pump blood, and accumulating excessive amounts of mucus so that it interferes with breathing and in serious infections, gill damage can occur evenly. This hyperplasia will then be followed by cell necrosis and ultimately kill all cells in the gills (Bullock, 1990; Setyawan 2015).

The structure of the skin of eels consists of three main layers, namely the epidermis, dermis and subcutis layers (Caruso et al., 2009). In addition, air exposure in this study caused epidermal erosion of the skin organs and increased mucus secretion. This is an adaptation mechanism to maintain the condition of body against environmental changes. Compared to other fish, eel skin has a thick structure and has a large enough capacity to secrete mucus. This is useful in preventing dry skin and staying moisturized and protecting the body surface from chemical damage and infection of microorganisms (Alexander \& Ingram, 1992; Tesch, 2003; Caruso et al., 2009; Methling, 2015). This was also reported by Harianto et al., (2020) eels that were kept in a wet system at a water level of 0.5 times their body height caused the gills and skin to work harder to balance the defense system of the body, as a result the gills experienced cell crenation or depletion.

\section{Conclusion}

Oxygen uptake in Anguilla bicolor bicolor eels when they were outside the water medium was $60.20 \%$ through the gills and $39.80 \%$ through the skin. The longer the eels are out of the water medium, the condition of the blood biochemistry, blood pictures and histological structure decreases (the fish are under stress conditions).

\section{Ethical Statement}

We ensured that the experiments followed the ethical guidelines of IPB University and confirmed that all experimental protocols were approved by IPB University.

\section{Funding Information}

This study was funded by the Indonesian Ministry of Finance through the Indonesia Endowment Fund for Education (LPDP) in the Beasiswa Unggulan Dosen Indonesia Dalam Negeri (BUDI-DN) program. 


\section{Author Contribution}

First author conducted the experiments and analysed the results. Second, Third, Fourth, and Fifth authors contributed to the development of the protocol and prepared the manuscript. All authors reviewed the manuscript.

\section{Conflict of Interest}

The author(s) declare that they have no known competing financial or non-financial, professional, or personal conflicts that could have appeared to influence the work reported in this paper.

\section{Acknowledgements}

We would like to thank the Indonesian Ministry of Finance through the Indonesia Endowment Fund for Education (LPDP) for providing the Beasiswa Unggulan Dosen Indonesia Dalam Negeri (BUDI-DN) as study and research grant.

\section{References}

Abdel-Tawwab, M., Hagras, A.E., Elbaghdady, H.A.M., Monier, M.N. (2014). Dissolved oxygen level and stocking density effects on growth, feed utilization, physiology, and innate immunity of Nile tilapia, Oreochromis niloticus. Journal of Applied Aquaculture, 26(4), 340-355. https://doi.org/10.1080/10454438.2014.959830

Abdel-Tawwab, M., Hagras, A.E., Elbaghdady, H.A.M., Monier, M.N. (2015). Effects of dissolved oxygen and fish size on Nile tilapia, Oreochromis niloticus (L.): growth performance, whole-body composition, and innate immunity. Aquaculture International, 23(5), 12611274.https://doi.org/10.1007/s10499-015-9882-y

Affandi, R., Rahardjo, M.F., \& Sulistiono, S. (1995). Distribution of Eel Juvenile, Anguilla spp. In Segara Anakan Lagoon, Cilacap, Central Java. Jurnal ilmu-ilmu Perairan dan Perikanan Indonesia, III (1), 27-38.

Alexander, J.B., \& Ingram, G.A. (1992). Noncellular non-specific defence mechanisms of fish. Annual Review of Fish Disease, 2, 249- 279. https://doi.org/10.1016/09598030(92)90066-7

Anderson, D.P., \& Siwicki A.K. (1993). Basic Hematology and Serology for Fish Health Programs. Paper presented in second symposium on diseases in Asian Aquaculture "Aquatic Animal Health and the Environment". Phuket, Thailand. 25-29th October 1993. p 185-202.

Angka, S.L., Mokoginta, I., \& Hamid, H. (1990). Anatomi dan histologi banding beberapa ikan air tawar yang dibudidayakan di Indonesia. Departemen Pendidikan dan Kebudayaan. Direktorat Jenderal Pendidikan Tinggi. Bogor. (p 146). Institut Pertanian Bogor.

Arai, T., Chino, N., \& Le, D.Q. (2013). Migration and habitat use of the tropical eels Anguilla marmorata and A. bicolor pacifica in Vietnam. Aquatic Ecology, 47(1), 57-65. https://doi.org/10.1007/s10452-012-9424-x

Arai, T., \& Kadir, A.S.R. (2017). Opportunistic spawning of tropical anguillid eels Anguilla bicolor bicolor and $A$. bengalensis bengalensis. Scientific Reports, 7, 41649. https://doi.org/10.1038/srep41649
Arai, T., \& Chino, N. (2018). Opportunistic migration and habitat use of the giant mottled eel Anguilla marmorata (Teleostei: Elopomorpha). Scientific Reports, 8, 5666. https://doi.org/10.1038/s41598-018-24011-z

Arai, T., \& Chino, N. (2019). Variationsin the migratory historyof the tropical catadromous eels Anguilla bicolor bicolor and A. bicolor pacificain south-east Asian waters. Journal of Fish Biology, 94(5), 1-27. https://doi.org/10.1111/jfb.13952

Berg, T., \& Steen, J.B. (1965). Physiological mechanisms for aerial respiration in the eel. Comparative. Biochemistry and Physiology, 15(4), 469-484. https://doi.org/10.1016/0010-406X(65)90147-7

Berg, T., \& Steen, J.B. (1966). Regulation of ventilation in eels exposed to air. Comparative. Biochemistry and Physiology, 18(3), 511-516. https://doi.org/10.1016/0010-406X(66)90235-0

Blaxhall, P.C., \& Daishley, K.W. (1973). Routine haematological methods for use with fish blood. Journal Fish Biology, 5(6):771-781. https://doi.org/10.1111/j.1095-8649.1973.tb04510.x

Bullock. 1990. Bacterial gill disease of freshwater fishes. Fish Disease Leaflet, 84, 1-17.

Cappello, T., Brandao, F., Guilherme, S., Santos, M.A., Maisano, M., Mauceri, A., Canario J., Pacheco, M., Pereira, P. (2016). Insights into mechanisms underlying mercuryinduced oxidative stress in gills of wild fish (Liza aurata) combining (1) H NMR metabolomics and conventional biochemical assays. Science. Of The Total Environment, 548-549, 13-24. https://doi.org/10.1016/j.scitotenv.2016.01.008

Caruso, G., Maricchiolo, G., Micale, V., Genovese, L., Caruso, R., Denaro, M.G. (2009) Physiological responses to starvation in the European eel (Anguilla anguilla): effects on haematological, biochemical, non-specific immune parameters and skin structures. Fish Physiology and Biochemistry, 36(1), 71-83. https://doi.org/10.1007/s10695-008-9290-6

Chatzifotis, S., Papadaki, M., Despoti, S., Roufidou, C., Antonopoulou, E. (2011). Effect of starvation and refeeding on reproductive indices, body weight, plasma metabolites and oxidative enzymes of sea bass (Dicentrarchus labrax). Aquaculture, 316(1-4), 53-59. https://doi.org/10.1016/j.aquaculture.2011.02.044

Chen, N., Wu, M., Tang, G.P., Wang, H.J., Huang, C.X., Wu, X.J., He, Y., Zhang, B., Huang, C.H., Liu, H., Wang, W.M., Wang, H.L. (2017). Effects of Acute Hypoxia and Reoxygenation on Physiological and Immune Responses and Redox Balance of Wuchang Bream (Megalobrama amblycephala Yih, 1955). Frontiers. Physiology, 8, 375. https://doi.org/10.3389/fphys.2017.00375

Chino, N., \& Arai, T. (2010). Habitat use and habitat transisons in the tropical eels (Anguilla bicolor bicolor). Environmental Biology of Fish, 89, 572 - 578. https://doi.org/10.1007/s10641-010-9677-y

De Domenico, E., Mauceri, A., Giordano, D., Maisano, M., Giannetto, A., Parrino, V., Natalotto, A., D’Agata A., Cappello, T., Fasulo, S. (2013). Biological responses of juvenile European seabass (Dicentrarchus labrax) exposed to contaminated sediments. Ecotoxicology and Environmental Safety, 97, 114-123. http://dx.doi.org/10.1016/j.ecoenv.2013.07.015

Diansyah, S., Budiardi, T., \& Sudrajat, A.O. (2014). Growth performance of 3-g Anguilla bicolor bicolor at different density. Journal Akuakultur Indonesia, 13(1), 46-53. 
https://doi.org/10.19027/jai.13.46-53

Dikic, D., Lisicic, D., Matic-Skoko, S., Tutman, P., Skaramuca, D., Franic, Z., Skaramuca, S. (2013). Comparative hematology of wild Anguilliformes (Muraena helena, L. 1758, Conger conger, L. 1758 and Anguilla anguilla L. 1758). Animal Biology, 63(1), 77-92. https://doi.org/10.1163/15707563-00002395

Dutra, B.K., da Silva, K.M., Zank, C., Conter, M.R., Oliveira, G.T. (2008). Seasonal variation of the effect of highcarbohydrate and high-protein diets on the intermediate metabolism of Parastacus brasiliensis (Crustacea, Decapoda, Parastacidae) maintained in the laboratory. Iheringia, Série Zoologia, Porto Alegre, 98(4), 433-440. http://dx.doi.org/10.1590/S0073-47212008000400003

Fazio, F., Marafioti, S., Arfuso, F., Piccione, G., Faggio, C. (2013). Comparative study of the biochemical and haematological parameters of four wild Tyrrhenian fish species. Veterinarni Medicina, 58(11), 576-581. https://doi.org/10.17221/7139-VETMED

Fekri, L., Affandi, R., Rahardjo, M.F., Budiardi, T., Simanjuntak, C.P.H., Fauzan, T., Indrayani. (2018). Pengaruh suhu terhadap kondisi fisiologis dan kinerja pertumbuhan elver ikan sidat Anguilla bicolor bicolor (McClelland, 1844). Jurnal Akuakultur Indonesia, 17(2), 181-190. https://doi.org/10.19027/jai.17(2):181-190.

Ferguson, R.A., \& Tufts, B.L. (1992). Physiological effects of brief air exposure in exhaustively exercised rainbow trout (Oncorhynchus mykiss): implications for "catch and release" fisheries. Canadian Journal of Fisheries and Aquatic Sciences, 49(6),1157-1162. https://doi.org/10.1139/f92-129

Flores-Lopes, F.A.B., Thomaz, A.T. (2011). Histopathologic alterations observed in fish gills as a tool in environmental monitoring. Braz. J. Biol, 71(1), 179-188.

Forster, M.E. (1981). Oxygen consumption and apnoea in the shortfin eel, Anguilla australis schmidtii. New Zealand Journal of Marine and Freshwater Research, 15(1), 8590. https://doi.org/10.1080/00288330.1981.9515900

Graham, J.B. (1997). Air-breathing fishes. Evolution, diversity and adaptation. (p 296). San Diego: Academic Press.

Hangalapura, B., Zwart, R., Engelsma, M., Haenen, O. (2007). Pathogenesis of Herpesvirus anguillae (HVA) in juvenile European eel Anguilla anguilla after infection by bath immersion. Diseases of Aquatic Organisms, 78(1), 13-22. https://doi.org/10.3354/dao01849

Harianto, E., Budiardi, T., \& Sudrajat, A.O. (2014). Growth performance of 7-g Anguilla bicolor bicolor at different density. Jurnal Akuakultur Indonesia, 13(2), 120-131. https://doi.org/10.19027/jai.13.120-131

Harianto, E., Supriyono, E., Budiardi, T., Affandi, R., Hadiroseyani, Y. (2020). Production performance and physiology response of Anguilla bicolor bicolor rearing with a wet, damp and dry system. Jurnal Iktiologi Indonesia, 20(2), 117-132. https://doi.org/10.32491/jii.v20i2.519

Haryono, H., \& Wahyudewantoro, G. (2016). Pemetaan habitat ruaya benih ikan sidat (Anguilla bicolor) dan potensinya di pantai Selatan Jawa. Omni-Akuatika, 12(3), 47-58. http://dx.doi.org/10.20884/1.oa.2016.12.3.123

Hidayaturrahmah, H., Muhamat, M., \& Santoso, H.B. (2015). Profil SGPT dan SGOT Ikan Nila (Oreochromis niloticus L.) di Sungai Riam Kanan Kalimantan Selatan. Jurnal Pharmascience, 2(2), 38-46.

http://dx.doi.org/10.20527/jps.v2i2.5821

Huertas, M., \& Cerda, J. (2006). Stocking density at early developmental stages affects growth and sex ratio in the european eel (Anguilla anguilla). Biology. Bulletin, 211(3), 286-296. http://dx.doi.org/10.2307/4134550

Hyde, D.A., Moon, T.W., \& Perry, S.F. (1987). Physiological consequences of prolonged aerial exposure in the American eel, Anguilla rostrata: Blood respiratory and acid-base status. Journal of Comparative Physiology $B$, 157, 635-642. https://doi.org/10.1007/BF00700984

Hyde, D.A., \& Perry, S.F. (1987). Acid-base and ionic regulation in the american eel (anguilla rostrata) during and after prolonged aerial exposure: branchial and renal adjustments. Journal of Experimental Biology, 133(1), 429-447. https://doi.org/10.1242/jeb.133.1.429

Jackim, E., \& La Roche, G. (1973). Protein synthesis in Fundulus heteroclitus muscle. Comparative Biochemistry and Physiology Part A: Physiology, 44(3), 851-866. https://doi.org/10.1016/0300-9629(73)90148-5

Javed, M., Ahmad, M.D.I., Usmani, N., Ahmad, M. (2017). Multiple biomarker responses (serum biochemistry, oxidative stress, genotoxicity and histopathology) in Channa punctatus exposed to heavy metal loaded waste water. Scientific Reports, 7, 1675. https://doi.org/10.1038/s41598-017-01749-6

Kim, J.H., Lee, K., Lee, D.G., Park, S.W., Yang, Y.S. (2014). Stimation of green-house-gas emissions from domestic eel farm. Bulletin of the Korean society of Fisheries Technolog, 50(1):058-066. https://doi.org/10.3796/KSFT.2014.50.1.058

Kulkarni, R., \& Pruthviraj, C.B. (2016). Blood creatinine and some enzyme levels in four species of indian carp fishes collected from a local aquatic body. International Letters of Natural Sciences, 60, 13-17.

https://doi.org/10.18052/www.scipress.com/ILNS.60.13

Krogh, A. (1904). Some experiments on the cutaneous respiration of vertebrate animals. Skandinavisches Archiv Für Physiologie, 16(2), 348-357. https://doi.org 10.1111/j.1748-1716.1904.tb01378.x

Lindsey, C.C. (1978). Form, function and the locomotory habits in fish. In W.S. Hoar \& D.J. Randall (Eds.), Fish Physiology vol. VII (pp. 1-100). NY: Academic Press.

McKenzie, D.J., Piccolella, M., Dalla Valle, A.Z., Taylor, E.W., Bolis, C.L. Steffensen, J.F. (2003). Tolerance of chronic hypercapnia by the European eel Anguilla anguilla. Journal of Experimental. Biology, 206(10), 1717-1726. https://doi.org/10.1242/jeb.00352

McKinnon, L.J. (2006). A Review of Eel Biology: Knowledge and Gaps. Report to EPA Victoria. P 39.

Methling, C. (2015). Cardio-respiratory Physiology of the European Eel (Anguilla anguilla) in Extreme Environments. Marine Biological Section, Department of Biology PhD School of Science, Faculty of Science, University of Copenhagen Denmark.

Mumford, S.L. (2004). Histology for Finfish. (2 Eds.), (pp. 1-12). Washington (US): Olympia Fish Health Center.

Perez-Jimenez, A., Guedes, M.J., Morales, A.E., Oliva-Teles, A. (2007). Metabolic responses to short starvation and refeeding in Dicentrarchus labrax effect of dietary composition. Aquaculture, 265(1-4), 325-335. https://doi.org/10.1016/j.aquaculture.2007.01.021

Perez-Rostro, C.I., Racotta, I.S., \& Ibarra, A.M., (2004). Decreased genetic variation in metabolic variables of Litopenaeus vannamei shrimp after exposure to acute hypoxia. Journal of Experimental Marine Biology and Ecology, 302(2), 189-200. https://doi.org/10.1016/j.jembe.2003.10.010 
Refaey, M.M., \& Li, D. (2018). Transport stress changes blood biochemistry, antioxidant defense system, and hepatic HSPS MRNA expressions of channel catfish Ictalurus punctatus. Frontiers in Physiology, 9, 1628. https://doi.org/10.3389/fphys.2018.01628

Robinet, T., \& Feunteun, E. (2002). First observations of shortfinned Anguilla bicolor bicolor and longfinned Anguilla marmorata silver eels in the reunion island. Bulletin Français de la Pêche et de la Pisciculture, 364, 87-95. https://doi.org/10.1051/kmae:2002004

Sancho, E., Andreau, Ó., Villarroel, M.J., Fernández-Vega, C., Tecles, F., Martínez-Subiela, S., Ceron JJ, Ferrando, M.D. (2016) European eel (Anguilla anguilla) plasma biochemistry alerts about propanil stress. Journal of Pesticide Science, 42(1), 7-15.

https://doi.org/10.1584/jpestics.D16-062

Scholander, P.F., \& Edwards, G.A. (1942). Volumetric Microrespirometer for Aquatic Organisms. Review of Scientific Instruments, 13(7), 292-295. https://doi.org/10.1063/1.1770038

Scholander, P.F. (1949). Volumetric Respirometer for Aquatic Animals. Review of Scientific Instruments, 20(12), 885887.https://doi.org/10.1063/1.1741421

Scholander, P.F., Dam, L.V., Claff, L.C., Kanwisher, J.W. (1955). Micro gasometric determination of dissolved oxygen and nitrogen. Biological Bulletin, 109(2), 328-334. https://doi.org/10.2307/1538732

Setyawan, A.C., Sukenda. Nuryat, S. 2015. Status Kesehatan Ikan Sidat (Anguilla sp.) Pada Perairan Umum dan Wadah Pemeliharaan Sementara. Jurnal Riset Akuakultur, 10 (1), 69-77

Sripriya, R., Kumar, K., \& Rajendran, K. (2015). Seasonal Variation of Serum Enzymes of Indian Freshwater Eel Anguila bicolor (Mcclelanand). International Journal of Fisheries and Aquatic Studies, 3(2), 50-54.

Tahmasebi-Kohyani, A., Keyvanshokooh, S., Nematollahi, A., Mahmoudi, N., Pasha-Zanoosi, H. (2012). Effects of dietary nucleotides supplementation on rainbow trout (Oncorhynchus mykiss) performance and acute stress response. Fish Physiology and Biochemistry, 38(2), 431440. https://doi.org/10.1007/s10695-011-9524-x

Tan, C., Sun, D., Tan, H., Liu, W., Luo, G., Wei, X. (2018). Effects of stocking density on growth, body composition, digestive enzyme levels and blood biochemical parameters of Anguilla marmorata in a recirculating aquaculture system. Turkish Journal of Fisheries and Aquatic Sciences, 18(1), 9-16. https://doi.org/10.4194/1303-2712-v18_1_02

Tang, Y., Liu, Y., Zhang, T., Li, J., Wang, X., Zhang, W., Zeng, G., Liu, S., Gua, L. (2019). Acute toxicity of divalent mercury ion to anguilla japonica from seawater and freshwater aquaculture and its efects on tissue structure. International Journal Environmental Research and Public Health, 16(11), 1965. https://doi.org/10.3390/ijerph16111965

Taqwa, F.H., Supriyono, E., Budiardi, T., Utomo, N.B.P., Affandi, R. (2018). Optimization of physiological status of glass eel (Anguilla bicolor bicolor) for transport by salinity and temperature acclimatization. AACL Bioflux, 11(3), 856867.

Tesch, F.W. (2003). The Eel. (5 Eds.), (P. 418), Oxford, UK: Blackwell Publishing Ltd.

Tomie, J.P.N., Cairn, D.K., \& Courtenay, S.C. (2013). How American eels Anguilla rostrata construct and respire in burrows. Aquatic Biology, 19(3), 287-296. https://doi.org/10.3354/ab00538

Trischitta, F., Takei, Y., \& Sébert, P. (2013). Eel Physiology. (1 Eds.), (pp. 378), CRC Press.

Van Waarde, A., Thillart, G.V.D., \& Kesbeke, F. (1983). Anaerobic energy metabolism of the European eel, Anguilla anguilla L. Journal of comparative physiology, 149, 469-475. https://doi.org/10.1007/BF00690005

Wedemeyer, G.A., \& Yasutake, W.T. (1977). Clinical methods for the assessment of the effect environmental stres on fish health. New York (US). Department of Interior Fish and Wildlife Service Technical, 89:1-17.

Wells, R.M.G., \& Baldwin, J. (2006). Plasma lactate and glucose flushes following burst swimming in silver trevally (Pseudocaranx dentex: Carangidae) support the "releaser" hypothesis. Comparative Biochemistry and Physiology, Part A, 143(3), 347-352. https://doi.org/10.1016/j.cbpa.2005.12.015

Yancheva, V., Velcheva, I., Stoyanova, S., Georgieva, E. (2016). Histological biomarkers in fish as a tool in ecological risk assessment and monitoring programs: a review. Applied Ecology and Environmental Research, 14(1), 47-75. https://doi.org/10.15666/aeer/1401_047075

Yang, J.L., \& Chen, H.C. (2003). Serum metabolic enzyme activities and hepatocyte ultrastructure of common carp after gallium exposure. Zoological Studie, 42(3), 455461. 